\title{
Effect of recombinant bovine somatotropin (rbST) treatment on follicular population and development in non-lactating dairy cows
}

\author{
Joao Alveiro Alvarado Rincón ${ }^{1}$ (D), Bruna Mion ${ }^{1}$ (D), Diego Andres Velasco Acosta² (D), Bernardo Garziera Gasperin ${ }^{1}$ (D), \\ Monique Tomazele Rovani ${ }^{3}$ (D), Lígia Margareth Cantarelli Pegoraro ${ }^{4}$ (D), \\ Marcio Nunes Corrêa ${ }^{1}$ (D), Augusto Schneider ${ }^{5 *}$ \\ ${ }^{1}$ Faculdade de Veterinária, Universidade Federal de Pelotas, Pelotas, RS, Brasil \\ ${ }^{2}$ Corporación Colombiana de Investigación Agropecuaria, Mosquera, Cundinamarca, Colombia \\ ${ }^{3}$ Instituto Federal Farroupilha, Frederico Westphalen, RS, Brasil \\ ${ }^{4}$ Embrapa Clima Temperado, Empresa Brasileira de Pesquisa Agropecuária, Pelotas, RS, Brasil \\ ${ }^{5}$ Faculdade de Nutrição, Universidade Federal de Pelotas, Pelotas, RS, Brasil
}

\begin{abstract}
The aim of this study was to evaluate the long-term effects of recombinant bovine somatotropin (rbST) on follicle population and ovulatory follicle development in non-lactating dairy cows. Twenty-one Jersey cows were allocated in rbST $(n=11)$ or control $(n=10)$ groups. On day -60 , cows in rbST group received $500 \mathrm{mg}$ of somatotropin (s.c. Lactotropin ${ }^{\circledR}$, Elanco). On day 0, control and rbST cows received an intravaginal progesterone-releasing device $\left(1.9\right.$ g, CIDR ${ }^{\circledR}$, Zoetis) and GnRH (100 mg, IM, Factrel ${ }^{\circledR}$, Zoetis). On day 8, cows received PGF2 $\alpha$ (25 mg, IM, Lutalyse $^{\circledR}$, Zoetis) and the CIDR ${ }^{\circledR}$ was removed. Twelve hours after device removal (D8), serum, follicular fluid and granulosa cells samples were collected. Serum and follicular concentration of estradiol (E2) and progesterone (P4) were analyzed. Total RNA was extracted from granulosa cells to measure gene expression of $L H C G R$, STAR, $H S D-3 B 1$, CYP11A1, CYP19A1, CYP17A1, IGFR and PAPPA by real-time PCR. Ultrasonography was performed on days $-60,-53,-46,-14,-7,0$ and 8 for antral follicle count. Results were analyzed by repeated measures ANOVA and t-test. There was no effect of rbST treatment on the number of follicles during the 60 days period, as well as no effect on serum and follicular fluid E2 and follicular fluid $\mathrm{P} 4$ at the moment of follicle aspiration. There was a reduction in PAPPA $(P=0.006), C Y P 11 A 1(P=0.04)$ and $C Y P 19 A 1(P=0.002)$ mRNA levels in granulosa cells of the pre-ovulatory follicle of rbST treated cows. In conclusion, a single dose of rbST did not have long-term effects on antral follicle population, serum and follicular E2/P4 concentrations in non-lactating dairy cows. Despite that, rbST injection decreased granulosa cell expression of genes related to steroidogenesis in the pre-ovulatory follicle.
\end{abstract}

Keywords: follicular population, gene expression, steroidogenesis.

\section{Introduction}

Over the past years, aiming to improve the reproductive efficiency of dairy cattle, several strategies involving mainly nutrition management (Roche, 2006)

*Corresponding author: augusto.schneider@ufpel.edu.br

Received: September 27, 2018

Accepted: September 11, 2019 and protocols for ovulation induction have been studied (Thatcher et al., 2002; Lucy, 2007). Both the duration and intensity of the postpartum negative energy balance (NEB) are negatively associated with reproductive performance (Butler and Smith, 1989). The growth and estradiol (E2) production by the first postpartum dominant follicle are key factors for a successful ovulation (Butler et al., 2006; Kawashima et al., 2006), and its impairment can be attributed to reduced luteinizing hormone pulses (Grainger et al., 1982) as well as decreased circulating insulin and insulin-like growth factor I (IGF-I) concentrations (Butler et al., 2006; Kawashima et al., 2007). In the early postpartum period, increased growth hormone (GH) and decreased insulin concentration facilitate adipose tissue mobilization and support milk production (Lucy et al., 2001). The metabolic status associated to NEB decreases the expression of liver GH receptor and, consequently, decreases serum IGF-I-concentration (Butler et al., 2003). In this context, cows ovulating the first postpartum dominant follicle have higher serum IGF-I concentration than cows with non-ovulatory follicles (Taylor et al., 2004; Butler et al., 2006). IGF-I acts as modulator of gonadotropin action in the ovary, stimulating proliferation and differentiation of granulosa and theca cells (Armstrong and Webb, 1997). Therefore, strategies have been studied to minimize the effects of NEB and increased serum IGF-I to anticipate the moment of the first postpartum ovulation and improve dairy cow reproductive performance.

Treatment with exogenous recombinant bovine somatotropin (rbST) is usually performed during the postpartum period, aiming to enhance efficiency of milk synthesis (Bauman, 1999) and improve persistence of lactation (Bauman, 1992). Peripartum rbST treatment promotes an increase in serum IGF-I concentration (Carriquiry et al., 2009) and glucose, and a decreased serum non-esterified fatty acids and beta-hydroxybutyrate concentration (Putnam et al., 1999). Despite positive effects on lactation, some studies suggest that rbST negatively affects reproductive performance in dairy cows in the long term (Cole et al., 1992; Kirby et al., 1997b; Santos et al., 2004). Interestingly, the prepartum treatment with rbST was associated with a shorter interval between calving and first ovulation in dairy cows (Schneider et al., 2012). Prepartum rbST treatment increased production of E2 and expression of key steroidogenic enzymes by the first 
postpartum dominant follicle (Acosta et al., 2017). These results suggest a long-term effect of rbST on ovarian function depending in what stage of lactation is used that is still not totally understood.

Previous studies have demonstrated that the GH/IGF-I axis is essential for the recruitment of primordial follicles in mammals (Saccon et al., 2017) and for the growth of larger follicles in cows (Shimizu et al., 2008). In this context, treatment of cows and heifers with rbST increased the number of small antral follicles (Buratini et al., 2000), follicles class 1 (3-5 mm) (Gong et al., 1991; Kirby et al., 1997a); class 2 (6-9mm) (Kirby et al., 1997a; Kassa et al., 2002) and class 3 (>10mm) (De la Sota et al., 1993; Kirby et al., 1997a). These studies suggest a role for the $\mathrm{GH} / \mathrm{IGF}-\mathrm{I}$ axis in increasing antral follicle population in cows. Follicular growth from early pre-antral stages up to ovulatory size requires approximately 60 to 80 days in cows (Lussier et al., 1987; Britt, 1991). Therefore, rbST treatment can have long-term effects on ovarian physiology, through increased recruitment of pre-antral follicles. Furthermore, evidence suggests that a higher antral follicular count in dairy cows is associated with healthier antral follicles (Ireland et al., 2008) and increased fertility (Martinez et al., 2016).

Based on these evidences the GH/IGF-I axis may play and indirect role in ovulatory follicle development through increased antral follicle population. However, previous reports indicate a negative effect of $\mathrm{GH} / \mathrm{rbST}$ on reproduction. Most studies with rbST were performed with lactating dairy cows for obvious practical reasons, however lactation can be a confounding factor in these studies, as rbST treatment increases milk production (Bauman, 1999). rbST intensifies NEB and has negative effects on the reproductive performance, suggesting that testing its effects on non-lactating cows could help better understand its physiology. Based on this, the aim of this study was to evaluate the long-term effect of rbST administration on follicle population and development of the ovulatory follicle in non-lactating dairy cows. Our hypothesis is that rbST can increase preantral follicle growth and recruitment and consequently have long-term beneficial effects on ovulatory follicle development.

\section{Methods}

All procedures performed in this experiment were approved by the Committee for Ethics in Animal Experimentation from the Federal University of Pelotas, protocol 4006-2015 (Pelotas, RS, Brazil).

\section{Animals and treatments}

The study was performed with non-lactating Jersey dairy cows $(n=21)$, kept in pasture. The cows had body condition score (BCS) between 2.5 and 3.5 (on a scale of 1 to 5) and were randomly (by BCS) assigned to two treatments: control $(n=10)$ and somatotropin ( $r b S T, n=11)$. The rbST group received one injection of somatotropin (500 mg/cow, s.c., Lactotropin ${ }^{\circledR}$, Elanco, SP, Brazil) 60 days before the beginning of synchronization protocol (Day -60). On day 0 , all cows received an intravaginal progesterone (P4)-releasing device (1.9 g, CIDR ${ }^{\circledR}$, Zoetis, NJ, USA) and a GnRH injection (100 mg, IM, Factrel ${ }^{\circledR}$, Zoetis). On Day 8, at the moment of $\mathrm{P} 4$ device withdrawal, all cows received an injection of PGF2 $\alpha$ (25 mg, i.m., Lutalyse ${ }^{\circledR}$, Zoetis). Transrectal ultrasonography (7.5 MHz linear array probe, Aquila pro, Esaote, São Paulo, SP, Brazil) was performed on days $-60,-53,-46,-14,-7,0$ and 8 for antral follicle count. All follicles detected by ultrasonography were counted and classified according to its diameter in three categories: Class $1(<6 \mathrm{~mm})$, Class $2(6-9 \mathrm{~mm})$ and Class $3(>9 \mathrm{~mm})$. On day 8 of the protocol, the diameter of the largest follicle was measured through ultrasonography.

\section{Serum, follicular fluid and granulosa cells collection}

Twelve hours after removal of the intravaginal P4 device cows received an epidural anesthesia (3 $\mathrm{ml}$ of $2 \%$ lidocaine) and the largest follicle aspirated by transvaginal ultrasound-guided aspiration (5.0 MHz convex transducer, Aquila Pro, Esaote). The follicular fluid and granulosa cells were recovered according to a previously described procedure (Schneider et al., 2013). Follicular fluid was centrifuged at $1500 \times \mathrm{G}$ for 10 minutes and the clear follicular fluid was stored at $-80^{\circ} \mathrm{C}$ for subsequent analysis. The pellet of granulosa cells was re-suspended in Trizol (Life Technologies, Carlsbad, CA, USA), homogenized and stored in liquid nitrogen.

Blood samples were collected by coccygeal venipuncture at the moment of follicle aspiration. Serum was obtained by centrifugation at $1000 \times \mathrm{G}$ for 15 minutes and stored at $-80^{\circ} \mathrm{C}$ for analysis of $\mathrm{E} 2$ and $\mathrm{P} 4$ concentrations.

\section{Hormonal analysis of serum and follicular fluid}

Serum and follicular fluid concentration of E2 and P4 were analyzed in a commercial laboratory by chemiluminescence methods (Laboratório Pasin, Santa Maria, RS, Brazil). Follicular fluid samples were diluted 1:500 before E2 analysis. Two samples (one from control group and one from rbST group) were excluded from further analysis since intrafollicular E2:P4 ratio was lower than 1, indicating that an atretic follicle was aspirated (Ireland and Roche, 1982; Cheong et al., 2016).

\section{Analysis of gene expression}

Total RNA was extracted from granulosa cell using the guanidine isothiocyanate protocol (Trizol, Life Technologies) following the manufacturer recommendations. The RNA was quantified in a spectrophotometer (Nanodrop Lite, Thermo Fischer Scientific Inc., USA) and adjusted to a concentration of $200 \mathrm{ng} / \mu \mathrm{L}$. Samples with a 260/280 nm absorbance ratio below 1.8 were excluded. Reverse transcription was performed with $1 \mu \mathrm{g}$ of total RNA in a volume of $20 \mu \mathrm{L}$ using the iScript Synthesis Kit (BioRad, Hercules, CA, USA) according to manufacturer instructions. Real time quantitative PCR was performed in duplicate in a 
final volume of $20 \mu \mathrm{L}$, using SYBR Green Mastermix (Applied Biosystems, Foster City, CA, USA), $10 \mu \mathrm{M}$ of each primer and $20 \mathrm{ng}$ of cDNA. For each assay, 45 cycles ( $95^{\circ} \mathrm{C}$ for 10 seconds and $60^{\circ} \mathrm{C}$ for 30 seconds) were run in the Real-Time ECO PCR system (ILLumina, San Diego, CA, USA) and a dissociation curve was included at the end of reaction to detect the specificity by the amplification of a single PCR product.

The H2A Histone Family Member Z (H2AFZ) gene was used as internal control and the target genes evaluated were: Luteinizing Hormone/Choriogonadotropin Receptor (LHCGR), Steroidogenic acute regulatory protein (STAR), Cytochrome P450 Family 11 Subfamily A Member 1 (CYP11A1), Cytochrome P450 Family 19 Subfamily A Member 1 (CYP19A1), Cytochrome P450 Family 17 Subfamily A Member 1 (CYP17A1), 3 beta-hydroxysteroid dehydrogenase $(H S D-3 B 1)$, pappalysin 1 (PAPPA) and IGF-I receptor $(I G F R)$. The respective primer sequences are described in Table 1.

The coefficient of variation was less than $2 \%$ for all primer pairs used. Relative expression was calculated using the $2^{\mathrm{A}-\mathrm{B}} / 2^{\mathrm{C}-\mathrm{D}}$ equation (where $\mathrm{A}$ is the cycle threshold [Ct] number for the gene of interest in the first control sample, B is the $\mathrm{Ct}$ number for the gene of interest in the analyzed sample, $\mathrm{C}$ is the $\mathrm{Ct}$ number for $H 2 A F Z$ in the first control sample, and $\mathrm{D}$ is the $\mathrm{Ct}$ number for $\mathrm{H} 2 \mathrm{AFZ}$ in the analyzed sample). The first control sample is a random reference sample from the control group and its value was 1.00 as expressed by this equation, and all other samples were calculated relative to this value. After that, all other results from the rbST group were divided by the mean relative expression of all the samples in the control group, which averaged 1.00 by this equation, to obtain the relative expression of genes of interest for the rbST compared to the control group.
The CYP17A1 gene is exclusively expressed in the theca interna cells and was used as an indicator of theca cell contamination in granulosa samples. Therefore, samples with $\mathrm{Ct}$ values lower than 30 for $C Y P 17 A 1$ were considered as contaminated and excluded from further gene expression analysis (Buratini et al., 2005). No sample was excluded according to this criteria.

\section{Statistical analysis}

Statistical analysis was performed using GraphPad Prism 5 software (GraphPad Software Inc., La Jolla, CA, USA). Continuous variables (i.e. gene expression, total follicular count, follicular diameter, serum and follicular concentration of E2, P4 and E2:P4 ratio) were analyzed using the Student's T test. Follicular count of each follicular category of follicles (Class 1, 2 and 3) were analyzed using two-way ANOVA. $P$ values lower than 0.05 were considered as significant. Results are presented as mean \pm standard error of the mean.

\section{Results}

There was no effect of treatment or treatment by time interaction on the number of total follicles $(P>0.05$, Figure 1), control group had $5.36 \pm 0.31$ follicles/cow and the bST group $5.08 \pm 0.28$ follicles/cow on average along the 60 days of experiment. Follicles were classified by size and there was no effect of rbST treatment on Class 1 ( $<6 \mathrm{~mm}$; control: $3.54 \pm 0.32$ and bST: $3.05 \pm 0.27$ follicles; $P=0.29)$, Class 2 (6-9 mm; control: $0.70 \pm 0.04$ and bST: $1.07 \pm 0.15$ follicles; $P=0.56)$ and Class 3 follicles ( $>9$ mm; control: $1.09 \pm 0.08$ and bST: $1.02 \pm 0.12$ follicles; $P=0.92$, Table 2). Moreover, the diameter of the aspirated follicle after the synchronization protocol at the end of the

Table 1 . Genes and primer sequences analyzed in this study.

\begin{tabular}{|c|c|c|}
\hline Gene & Sequence $5^{\prime} \rightarrow 3^{\prime}$ & Reference \\
\hline \multirow[t]{2}{*}{$H 2 A F Z$} & F: GAGGAGCTGAACAAGCTGTTG & Portela et al. (2010) \\
\hline & R: TTGTGGTGGCTCTCAGTCTTC & \\
\hline \multirow[t]{2}{*}{$L H C G R$} & F: TGACTATGGTTTCTGCTTACCCAA & Spicer et al. (2008) \\
\hline & R: CCATAATGTCTTCACAGGGATTGA & \\
\hline \multirow[t]{2}{*}{ STAR } & F: TCGCGGCTCTCTCCTAGGT & Spicer et al. (2008) \\
\hline & R: CTGCCGGCTCTCCTTCTTC & \\
\hline \multirow[t]{2}{*}{ CYP11A1 } & F: CTTCATCCCACTGCTGAATCC & Tajima et al. (2005) \\
\hline & R: GGTGATGGACTCAAAGGCAAA & \\
\hline \multirow[t]{2}{*}{ CYP19A1 } & F: TGCCAAGAATGTTCCTTACAGGTA & Spicer et al. (2008) \\
\hline & R: CACCATGGCGATGTACTTTCC & \\
\hline \multirow[t]{2}{*}{ CYP17A1 } & F: GAATGCCTTTGCCCTGTTCA & Buratini et al. (2005) \\
\hline & R: CGCGTTTGAACACAACCCTT & \\
\hline \multirow[t]{2}{*}{$H S D-3 B 1$} & F: CCAAGCAGAAAACCAAGGAG & Nishimura et al. (2006) \\
\hline & R: ATGTCCACGTTCCCATCATT & \\
\hline \multirow[t]{2}{*}{$P A P P A$} & F: TGGAGAACGCTTCGCTCAACTG & Rodríguez et al. (2015) \\
\hline & R: ACGCTGGGTCCTGTCTGGCTTT & \\
\hline \multirow[t]{2}{*}{$I G F R$} & F: CACGCCTTGGTCTCCTTGTCCT & Rodríguez et al. (2015) \\
\hline & R: CGTCACTTCCTCCATGCGGTAAAT & \\
\hline
\end{tabular}




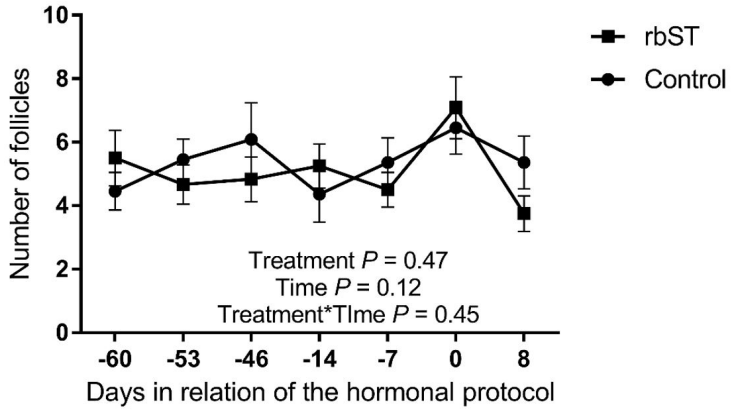

Figure 1. Total follicular count at different moments for recombinant bovine somatotropin (rbST) and control groups. rbST injection was performed 60 days before the beginning of the protocol. Values are presented as mean \pm standard error and the differences $(P<0.05)$ are represented by different lowercase letters.

Table 2. Mean number of follicles from Class $1(<6 \mathrm{~mm})$, $2(6-9 \mathrm{~mm})$ and $3(>9 \mathrm{~mm})$ in cows receiving recombinant bovine somatotropin (rbST) and control. Values are presented as mean \pm standard error and the differences $(P<0.05)$ are represented by different lowercase letters.

\begin{tabular}{lccc}
\hline \multirow{2}{*}{ Group } & \multicolumn{3}{c}{ Follicular category } \\
\cline { 2 - 4 } & Class 1 & Class 2 & Class 3 \\
\hline Control & $3.54 \pm 0.32$ & $0.70 \pm 0.04$ & $1.09 \pm 0.08$ \\
rbST & $3.05 \pm 0.27$ & $1.07 \pm 0.15$ & $1.02 \pm 0.12$ \\
\hline
\end{tabular}

Mean \pm SEM. study was not different between control $(15.02 \pm 1.16 \mathrm{~mm})$ and rbST groups $(16.47 \pm 1.63 \mathrm{~mm}, P=0.48)$.

At the moment of $\mathrm{P} 4$ device removal in the synchronization protocol, serum $\mathrm{P} 4$ concentration was less than $1 \mathrm{ng} / \mathrm{mL}$ in both groups (Control: $0.50 \pm 0.09$ and $\mathrm{bST}$ : $0.47 \pm 0.79 \mathrm{ng} / \mathrm{mL}$ ), indicating successful luteolysis and no levels of P4 that could interfere with follicle growth (Ginther and Beg, 2012). At the moment of follicle aspiration there was no difference between control and rbST group for $\mathrm{E} 2$ concentration in serum $(17.5 \pm 2.2$ and $21.5 \pm 2.6 \mathrm{pg} / \mathrm{mL}$, respectively, $P=0.27)$. Additionally, the concentration of E2 $(1356 \pm 371.3$ and $1532 \pm 256.5 \mathrm{ng} / \mathrm{mL}$, respectively, $P=0.71)$ and $\mathrm{P} 4(67.8 \pm 16.9$ and $154.6 \pm 45.3 \mathrm{ng} / \mathrm{mL}$, respectively, $P=0.08$ ) in the follicular fluid of the largest follicle after the synchronization protocol was not different between groups. There was also no difference in the follicular fluid E2:P4 ratio of the largest follicle aspirated $(25.9 \pm 6.6$ and $16.6 \pm 3.8$, respectively, $P=0.26$, Figure 2).

Regarding granulosa cells gene expression in the pre-ovulatory follicle aspirated, cows treated with $\mathrm{rbST}$ had lower expression of the IGFBP cleaving PAPPA enzyme $(P=0.006)$, and steroidogenic enzymes, $C Y P 11 A 1$ $(P=0.04)$ and $C Y P 19 A 1(P=0.002)$. There was no difference between groups for $L H C G R, S T A R, H S D-3 B 1$ and IGFR gene expression (Figure 3).

b

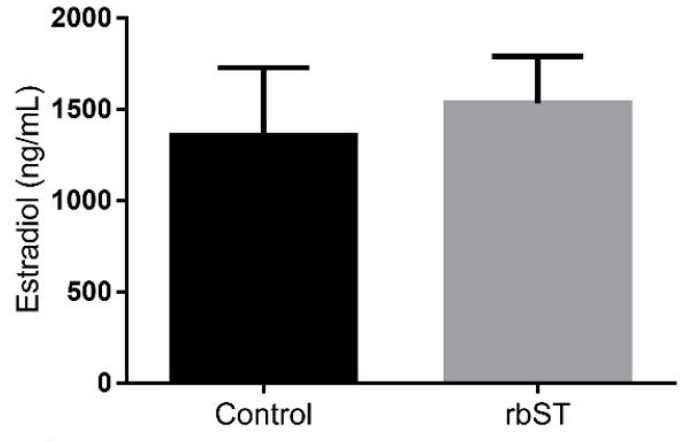

d

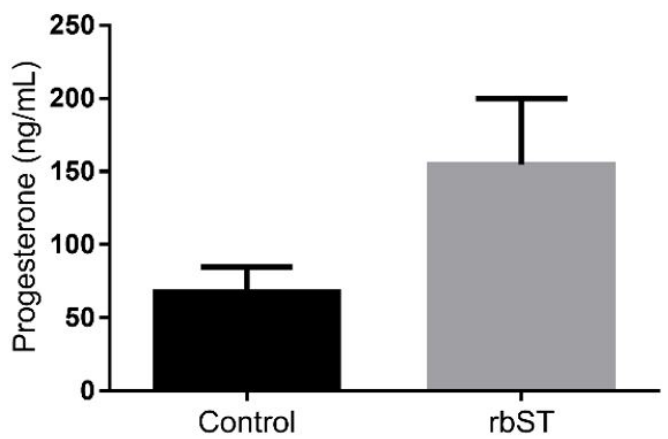

Figure 2. a) Serum estradiol (E2) concentration, b) Follicular E2 concentration, c) Follicular E2:P4 ratio and d) Follicular progesterone $(\mathrm{P} 4)$ concentration for cows treated with recombinant bovine somatotropin (rbST) or control twelve hours after removal of the intravaginal P4. rbST injection was performed 60 days before the beginning of the protocol. Values are presented as mean \pm standard error and the differences $(P<0.05)$ are represented by different lowercase letters. 

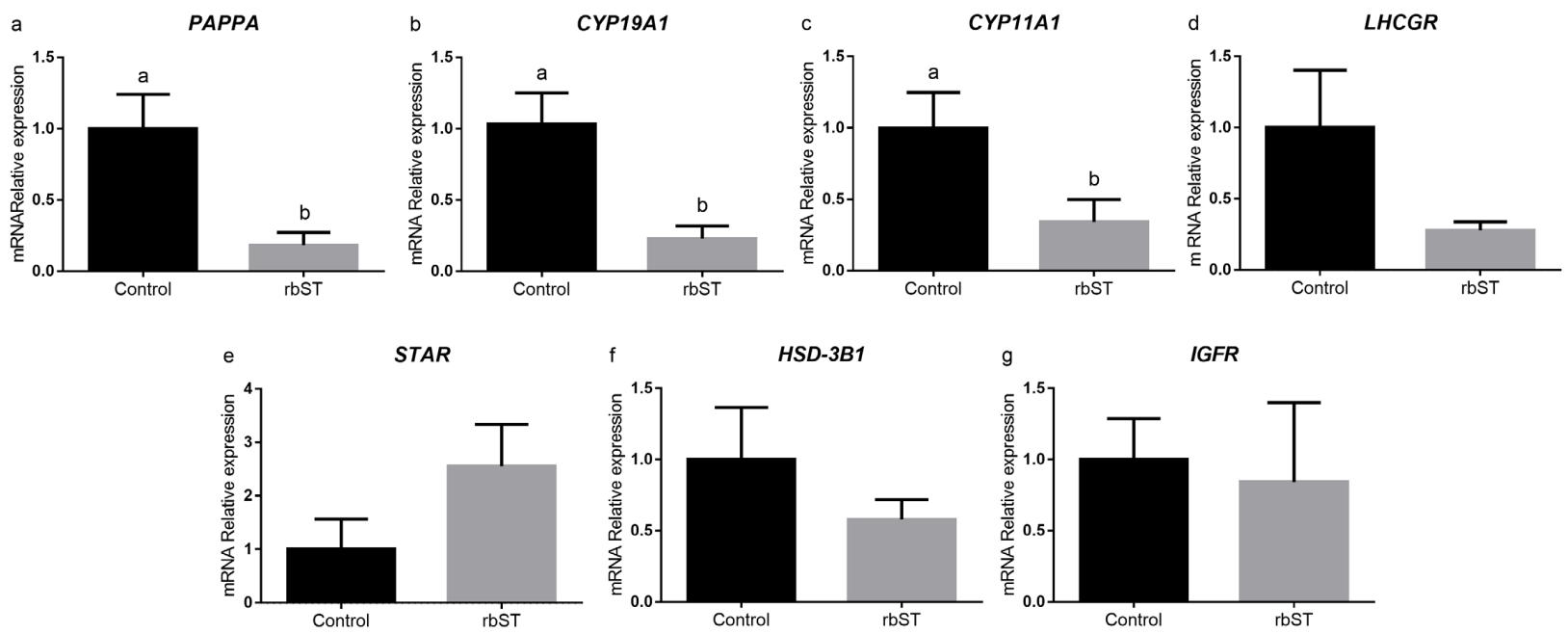

Figure 3. Pre-ovulatory follicle granulosa cell gene expression for cows treated with recombinant bovine somatotropin $(\mathrm{rbST})$ or control twelve hours after removal of the intravaginal P4. rbST injection was performed 60 days before the beginning of the protocol. Values are presented as mean \pm standard error and the differences $(P<0.05)$ are represented by different lowercase letters.

\section{Discussion}

The present study investigated long-term effects of rbST treatment on follicular-function in cows. Our main finding suggests that rbST treatment did not affect follicular population or development in the long term. However, there was a reduction in gene expression of steroidogenic enzymes in granulosa cells from pre-ovulatory follicles after the end of the treatment. These findings suggest a long-term effect of rbST on follicle maturation. Although an effect on important genes involved with steroidogenesis was detected, no direct impact of the treatment on estrogen production was observed.

Several studies shown that rbST treatment increases small follicles population in cows and heifers (Gong et al., 1991; De la Sota et al., 1993; Kirby et al., 1997a; Jimenez-Krassel et al., 1999; Buratini et al., 2000; Kassa et al., 2002). However, in our current study, a single rbST injection was not able to affect the number of follicle or its development. Most studies mentioned before performed more than one rbST injection, only Buratini et al. (2000) also performed a single rbST injection. However, the effect of this single rbST injection on follicular population was evaluated until 11 days after treatment, while we evaluated until 60 days after the rbST injection. We understand that a longer period is needed to evaluate the effect of rbST injection on follicular recruitment, as the follicular development from pre-antral to antral stages requires approximately 40 days in cows (Lussier et al., 1987). Therefore, the evaluation of dominant follicle growth 60 days after rbST injection was performed aiming to select an ovulatory follicle that was in the preantral stages of development at the moment of rbST injection. The long-term effect of rbST injection on follicular response was also evaluated by Kassa et al. (2002). In this study, the rbST effect was evaluated up to 58 days and a reduction in recruitment of Class 2 follicles was observed, suggesting that rbST treatment stimulates greater follicle dominance. However, in that study, fat supplementation was also performed and could interfere with results. It is still unclear how rbST treatment alone can affect follicular population in the long term. Despite that, our current study suggests no significant effect on long-term follicle population after a single rbST injection in cows.

Previous studies showed that rbST treatment in postpartum dairy cows can negatively affects estrous expression and reproductive performance (Cole et al., 1992; Kirby et al., 1997a; Santos et al., 2004). Nevertheless, prepartum rbST treatment improved ovulation and steroidogenesis of the first postpartum dominant follicle in dairy cows (Schneider et al., 2012; Acosta et al., 2017). In these studies, the direct effects of rbST on the ovaries were always influenced by the indirect effect of rbST on adaptation to lactation and negative energy balance. Therefore, we hypothesized that similar changes on steroidogenesis of pre-ovulatory follicles of rbST treated non-lactating cows in would be observed the current study. However, no difference was observed in ovulatory follicle growth pattern and concentration of E2 and P4 in serum or follicular fluid of rbST treated cows. Other studies also did not find an effect of rbST treatment in E2 concentrations (Gong et al., 1991; Kirby et al., 1997a; Jimenez-Krassel et al., 1999). Nevertheless, Rivera et al. (2010) observed a tendency of rbST treated cows to have higher concentration of E2 by the end of a FTAI protocol. De la Sota et al. (1993) also observed higher E2 concentration in the first 12 days of rbST treatment, but this difference disappeared after the end of treatment. Others reported that $\mathrm{rbST}$ treatment decreased the size of estrogen-active follicles during treatment (Jimenez-Krassel et al., 1999). Based on these evidences, it is still unclear how rbST can affect long term follicular development. In our study, rbST treatment did not affect small follicles population and this could explain also 
the lack of effect on ovulatory follicle growth and steroid production long after the end of treatment. GH has many functions in different reproductive tissues (Carlsson et al., 1992; Silva et al., 2009) we have to consider that GH effects in other organs and tissues (pituitary, uterus, CL, among others) may affected the response hypothesized for small pre-antral follicles.

The CYPs are members of the cytochrome P450 superfamily and are necessary for conversion of cholesterol into steroids precursors (Bao and Garverick, 1998) and production of estrone, estriol and E2 (Neunzig et al., 2017). We observed reduced expression of CYP11A1 and CYP19A1 in the granulosa cells of the pre-ovulatory follicles of rbST treated cows, suggesting that rbST had a negative impact on steroidogenesis pathways. Similarly, the reduction of $P A P P A$ expression in granulosa cells from rbST treated cows can lead to decreased follicular IGF-I bioavailability. In the ovary, IGF-I bioavailability is regulated by insulin-like growth factor-bindind proteins (IGFBPs) (Yakar and Adamo, 2012) and PAPPA (Sudo et al., 2007). The intrafollicular cleavage of IGFBP4 performed by PAPPA can increase IGF-I bioavailability and stimulate granulosa cell proliferation and steroidogenesis (Mazerbourg et al., 2001). In this sense, decreased PAPPA secretion by granulosa cells of rbST treated cows could decrease steroidogenesis. This observation, added to the reduced granulosa cell CYP11A1 and $C Y P 19 A 1$ expression in rbST treated cows, suggests a reduced ability of the pre-ovulatory follicle to produce E2 (Neunzig et al., 2017). However, we did not difference in follicular E2 and P4 concentrations. This could be due the short interval between $\mathrm{P} 4$ device removal and follicle aspiration, which did not allow enough time to reflect these differences in the intrafollicular accumulation of E2 and P4. Overall, our findings are in alignment with previous observations that rbST can reduce estrous response in postpartum dairy cows (Kirby et al., 1997a; Santos et al., 2004).

Poor reproductive performance postpartum is associated with a more severe NEB, greater insulin resistance, fewer LH pulses and lower follicular fluid androstenedione and E2 concentration (Cheong et al., 2016). Previous studies suggested that administration of rbST could help improve reproductive performance due its positive effect in glucose metabolism (Gohary et al., 2014) and serum IGF-I concentration during the development of the first postpartum follicular wave (Schneider et al., 2012; Silva et al., 2017). It is well know in dairy cows that the early postpartum severe NEB is associated with reduced IGF-I synthesis (Fenwick et al., 2008). However, we in our study we used non-lactating cows that were not in NEB, which could attenuate the positive effects of rbST in the ovarian physiology. Our results suggest that no significant improvement in reproductive performance should be expected when associating rbST injection to FTAI protocols in non-lactating cows.

In conclusion, a single injection of $\mathrm{rbST}$ in non-lactating dairy cows did not have long-term effects on follicle population, serum and follicular fluid E2 and P4 concentrations in the pre-ovulatory follicle. However, rbST has decreased expression of genes related to the synthesis of the steroid hormones by the granulosa cells of the pre-ovulatory follicle.

\section{Acknowledgements}

This work was supported by FAPERGS, CNPq and CAPES.

\section{References}

Acosta DAV, Schneider A, Jacometo CB, Rincon JA, Cardoso F, Correa MN. Effect of bovine somatotropin injection in late pregnant Holstein heifers on metabolic parameters and steroidogenic potential of the first postpartum dominant follicle. Theriogenology. 2017;104:164-72. http://dx.doi. org/10.1016/j.theriogenology.2017.08.024. PMid:28863349.

Armstrong DG, Webb R. Ovarian follicular dominance: the role of intraovarian growth factors and novel proteins. Rev Reprod. 1997;2(3):139-46. http://dx.doi.org/10.1530/ ror.0.0020139. PMid:9414477.

Bao B, Garverick HA. Expression of steroidogenic enzyme and gonadotropin receptor genes in bovine follicles during ovarian follicular waves: a review. J Anim Sci. 1998;76(7):1903-21. http://dx.doi.org/10.2527/1998.7671903x. PMid:9690647.

Bauman DE. Bovine somatotropin and lactation: from basic science to commercial application. Domest Anim Endocrinol. 1999;17(2-3):101-16. http://dx.doi.org/10.1016/ S0739-7240(99)00028-4. PMid:10527114.

Bauman DE. Bovine somatotropin: review of an emerging animal technology. J Dairy Sci. 1992;75(12):3432-51. http://dx.doi.org/10.3168/jds.S0022-0302(92)78119-3. PMid:1474210.

Britt JH. Impacts of early postpartum metabolism on follicular development and fertility. Bovine Practitioner Proc. 1991;24:39-43.

Buratini J Jr, Price CA, Visintin JA, Bo GA. Effects of dominant follicle aspiration and treatment with recombinant bovine somatotropin (BST) on ovarian follicular development in nelore (Bos indicus) heifers. Theriogenology. 2000;54(3):42131. http://dx.doi.org/10.1016/S0093-691X(00)00359-9. PMid:11051325.

Buratini J Jr, Teixeira AB, Costa IB, Glapinski VF, Pinto MG, Giometti IC, Barros CM, Cao M, Nicola ES, Price CA. Expression of fibroblast growth factor- 8 and regulation of cognate receptors, fibroblast growth factor receptor-3c and -4, in bovine antral follicles. Reproduction. 2005;130(3):34350. http://dx.doi.org/10.1530/rep.1.00642. PMid:16123241.

Butler ST, Marr AL, Pelton SH, Radcliff RP, Lucy MC, Butler WR. Insulin restores $\mathrm{GH}$ responsiveness during lactation-induced negative energy balance in dairy cattle: effects on expression of IGF-I and GH receptor 1A. J Endocrinol. 2003;176(2):205-17. http://dx.doi.org/10.1677/ joe.0.1760205. PMid:12553869.

Butler ST, Pelton SH, Butler WR. Energy balance, metabolic status, and the first postpartum ovarian follicle wave in cows administered propylene glycol. J Dairy Sci. 
Rincón et al. Effect of rbST on follicle development

2006;89(8):2938-51. http://dx.doi.org/10.3168/jds.S00220302(06)72566-8. PMid:16840609.

Butler WR, Smith RD. Interrelationships between energy balance and postpartum reproductive function in dairy cattle. J Dairy Sci. 1989;72(3):767-83. http://dx.doi.org/10.3168/ jds.S0022-0302(89)79169-4. PMid:2654227.

Carlsson B, Bergh C, Bentham J, Olsson JH, Norman MR, Billig H, Roos P, Hillensjö T. Expression of functional growth hormone receptors in human granulosa cells. Hum Reprod. 1992;7(9):1205-9. http://dx.doi.org/10.1093/ oxfordjournals.humrep.a137827. PMid:1478998.

Carriquiry M, Weber WJ, Dahlen CR, Lamb GC, Baumgard LH, Crooker BA. Production response of multiparous Holstein cows treated with bovine somatotropin and fed diets enriched with n-3 or n-6 fatty acids. J Dairy Sci. 2009;92(10):4852-64. http://dx.doi.org/10.3168/jds.20081673. PMid:19762801.

Cheong SH, Sa Filho OG, Absalon-Medina VA, Pelton SH, Butler WR, Gilbert RO. Metabolic and endocrine differences between dairy cows that do or do not ovulate first postpartum dominant follicles. Biol Reprod. 2016;94(1):18. http:// dx.doi.org/10.1095/biolreprod.114.127076. PMid:26632612.

Cole WJ, Eppard PJ, Boysen BG, Madsen KS, Sorbet RH, Miller MA, Hintz RL, White TC, Ribelin WE, Hammond BG, Collier RJ, Lanza GM. Response of dairy cows to high doses of a sustained-release bovine somatotropin administered during two lactations. 2. Health and reproduction. J Dairy Sci. 1992;75(1):111-23. http://dx.doi.org/10.3168/jds. S0022-0302(92)77745-5. PMid:1541726.

De la Sota RL, Lucy MC, Staples CR, Thatcher WW. Effects of recombinant bovine somatotropin (sometribove) on ovarian function in lactating and nonlactating dairy cows. J Dairy Sci. 1993;76(4):1002-13. http://dx.doi.org/10.3168/ jds.S0022-0302(93)77428-7. PMid:8486832.

Fenwick MA, Fitzpatrick R, Kenny DA, Diskin MG, Patton J, Murphy JJ, Wathes DC. Interrelationships between negative energy balance (NEB) and IGF regulation in liver of lactating dairy cows. Domest Anim Endocrinol. 2008;34(1):3144. http://dx.doi.org/10.1016/j.domaniend.2006.10.002. PMid:17137745.

Ginther OJ, Beg MA. Dynamics of circulating progesterone concentrations before and during luteolysis: a comparison between cattle and Horses. Biol Reprod. 2012;86(6):170. http:/ dx.doi.org/10.1095/biolreprod.112.099820. PMid:22460665.

Gohary K, LeBlanc SJ, Lissemore KD, Overton MW, Von Massow M, Duffield TF. Effect of prepartum administration of recombinant bovine somatotropin on health and performance of lactating dairy cows. J Dairy Sci. 2014;97(10):6231-41. http://dx.doi.org/10.3168/jds.2014-8048. PMid:25087023.

Gong JG, Bramley T, Webb R. The effect of recombinant bovine somatotropin on ovarian function in heifers: follicular populations and peripheral hormones. Biol
Reprod. 1991;45(6):941-9. http://dx.doi.org/10.1095/ biolreprod45.6.941. PMid:1805998.

Grainger C, Wilhelms G, McGowan A. Effect of body condition at calving and level of feeding in early lactation on milk production of dairy cows. Aust J Exp Agric. 1982;22(115):9-17. http://dx.doi.org/10.1071/EA9820009.

Ireland JJ, Roche JF. Development of antral follicles in cattle after prostaglandin-induced luteolysis: changes in serum hormones, steroids in follicular fluid, and gonadotropin receptors. Endocrinology. 1982;111(6):2077-86. http:// dx.doi.org/10.1210/endo-111-6-2077. PMid:6291909.

Ireland JL, Scheetz D, Jimenez-Krassel F, Themmen AP, Ward F, Lonergan P, Smith GW, Perez GI, Evans AC, Ireland JJ. Antral follicle count reliably predicts number of morphologically healthy oocytes and follicles in ovaries of young adult cattle. Biol Reprod. 2008;79(6):1219-25. http:// dx.doi.org/10.1095/biolreprod.108.071670. PMid:18768912.

Jimenez-Krassel F, Binelli M, Tucker HA, Ireland JJ. Effect of long-term infusion with recombinant growth hormonereleasing factor and recombinant bovine somatotropin on development and function of dominant follicles and corpora lutea in Holstein cows. J Dairy Sci. 1999;82(9):1917-26. http://dx.doi.org/10.3168/jds.S0022-0302(99)75427-5. PMid:10509250.

Kassa T, Ambrose JD, Adams AL, Risco C, Staples CR, Thatcher MJ, Van Horn HH, Garcia A, Head HH, Thatcher WW. Effects of whole cottonseed diet and recombinant bovine somatotropin on ovarian follicles in lactating dairy cows. J Dairy Sci. 2002;85(11):2823-30. http://dx.doi. org/10.3168/jds.S0022-0302(02)74369-5. PMid:12487449.

Kawashima C, Kaneko E, Montoya CA, Matsui M, Yamagishi N, Matsunaga N, Ishii M, Kida K, Miyake Y, Miyamoto A. Relationship between the first ovulation within three weeks postpartum and subsequent ovarian cycles and fertility in high producing dairy cows. J Reprod Dev. 2006;52(4):47986. http://dx.doi.org/10.1262/jrd.18003. PMid:16627955.

Kawashima C, Sakaguchi M, Suzuki T, Sasamoto Y, Takahashi Y, Matsui M, Miyamoto A. Metabolic profiles in ovulatory and anovulatory primiparous dairy cows during the first follicular wave postpartum. J Reprod Dev. 2007;53(1):113-20. http://dx.doi.org/10.1262/jrd.18105. PMid:17043386.

Kirby CJ, Smith MF, Keisler DH, Lucy MC. Follicular function in lactating dairy cows treated with sustainedrelease bovine somatotropin. J Dairy Sci. 1997a;80(2):27385. http://dx.doi.org/10.3168/jds.S0022-0302(97)75935-6. PMid:9058268.

Kirby CJ, Wilson SJ, Lucy MC. Response of dairy cows treated with bovine somatotropin to a luteolytic dose of prostaglandin F2 alpha. J Dairy Sci. 1997b;80(2):286-94. http://dx.doi.org/10.3168/jds.S0022-0302(97)75936-8. PMid:9058269. 
Lucy MC, Jiang H, Kobayashi Y. Changes in the somatotrophic axis associated with the initiation of lactation. J Dairy Sci. 2001;84:113-9. http://dx.doi.org/10.3168/jds.S00220302(01)70205-6.

Lucy MC. Fertility in high-producing dairy cows: reasons for decline and corrective strategies for sustainable improvement. Soc Reprod Fertil Suppl. 2007;64(1):237-54. http://dx.doi. org/10.5661/RDR-VI-237. PMid:17491151.

Lussier JG, Matton P, Dufour JJ. Growth rates of follicles in the ovary of the cow. J Reprod Fertil. 1987;81(2):301-7. http://dx.doi.org/10.1530/jrf.0.0810301. PMid:3430454.

Martinez MF, Sanderson N, Quirke LD, Lawrence SB, Juengel JL. Association between antral follicle count and reproductive measures in New Zealand lactating dairy cows maintained in a pasture-based production system. Theriogenology. 2016;85(3):466-75. http://dx.doi.org/10.1016/j. theriogenology.2015.09.026. PMid:26489910.

Mazerbourg S, Overgaard MT, Oxvig C, Christiansen M, Conover CA, Laurendeau I, Vidaud M, Tosser-Klopp G, Zapf J, Monget P. Pregnancy-associated plasma protein-A (PAPP-A) in ovine, bovine, porcine, and equine ovarian follicles: involvement in IGF binding protein-4 proteolytic degradation and mRNA expression during follicular development. Endocrinology. 2001;142(12):5243-53. http:// dx.doi.org/10.1210/endo.142.12.8517. PMid:11713222.

Neunzig J, Milhim M, Schiffer L, Khatri Y, Zapp J, Sanchez-Guijo A, Hartmann MF, Wudy SA, Bernhardt R. The steroid metabolite 16(beta)-OH-androstenedione generated by CYP21A2 serves as a substrate for CYP19A1. J Steroid Biochem Mol Biol. 2017;167:182-91. http:// dx.doi.org/10.1016/j.jsbmb.2017.01.002. PMid:28065637.

Nishimura R, Sakumoto R, Tatsukawa Y, Acosta TJ, Okuda K. Oxygen concentration is an important factor for modulating progesterone synthesis in bovine corpus luteum. Endocrinology. 2006;147(9):4273-80. http://dx.doi. org/10.1210/en.2005-1611. PMid:16740971.

Portela VM, Machado M, Buratini J Jr, Zamberlam G, Amorim RL, Goncalves P, Price CA. Expression and function of fibroblast growth factor 18 in the ovarian follicle in cattle. Biol Reprod. 2010;83(3):339-46. http://dx.doi.org/10.1095/ biolreprod.110.084277. PMid:20484739.

Putnam DE, Varga GA, Dann HM. Metabolic and production responses to dietary protein and exogenous somatotropin in late gestation dairy cows. J Dairy Sci. 1999;82(5):982-95. http://dx.doi.org/10.3168/jds.S0022-0302(99)75318-X. PMid:10342237.

Rivera F, Narciso C, Oliveira R, Cerri RL, Correa-Calderon A, Chebel RC, Santos JE. Effect of bovine somatotropin $(500 \mathrm{mg})$ administered at ten-day intervals on ovulatory responses, expression of estrus, and fertility in dairy cows. J Dairy Sci. 2010;93(4):1500-10. http://dx.doi.org/10.3168/ jds.2009-2489. PMid:20338427.
Roche JF. The effect of nutritional management of the dairy cow on reproductive efficiency. Anim Reprod Sci. 2006;96(3-4):282-96. http://dx.doi.org/10.1016/j. anireprosci.2006.08.007. PMid:16996705.

Rodríguez FM, Colombero M, Amweg AN, Huber E, Gareis NC, Salvetti NR, Ortega HH, Rey F. Involvement of PAPP-A and IGFR1 in cystic ovarian disease in cattle. Reprod Domest Anim. 2015;50(4):659-68. http://dx.doi. org/10.1111/rda.12547. PMid:26031184.

Saccon TD, Moreira F, Cruz LA, Mondadori RG, Fang Y, Barros CC, Spinel L, Bartke A, Masternak MM, Schneider A. Ovarian aging and the activation of the primordial follicle reserve in the long-lived Ames dwarf and the short-lived bGH transgenic mice. Mol Cell Endocrinol. 2017;455:23-32. http://dx.doi.org/10.1016/j.mce.2016.10.015. PMid:27771355.

Santos JE, Juchem SO, Cerri RL, Galvao KN, Chebel RC, Thatcher WW, Dei CS, Bilby CR. Effect of bST and reproductive management on reproductive performance of Holstein dairy cows. J Dairy Sci. 2004;87(4):868-81. http://dx.doi.org/10.3168/jds.S0022-0302(04)73231-2. PMid:15259221.

Schneider A, Absalon-Medina VA, Esposito G, Correa MN, Butler WR. Paraoxonase (PON) 1, 2 and 3 expression in granulosa cells and PON1 activity in follicular fluid of dairy cows. Reprod Domest Anim. 2013;48(6):989-94. http:// dx.doi.org/10.1111/rda.12198. PMid:23758560.

Schneider A, Schwegler E, Montagner P, Hax LT, Schmitt E, Pfeifer LF, Del Pino FA, Bianchi I, Paludo GR, Correa MN. Effect of prepartum somatotropin injection in late-pregnant Holstein heifers on metabolism, milk production and postpartum resumption of ovulation. Animal. 2012;6(6):935-40. http:// dx.doi.org/10.1017/S1751731111002321. PMid:22558964.

Shimizu T, Murayama C, Sudo N, Kawashima C, Tetsuka M, Miyamoto A. Involvement of insulin and growth hormone (GH) during follicular development in the bovine ovary. Anim Reprod Sci. 2008;106(1-2):143-52. http://dx.doi. org/10.1016/j.anireprosci.2007.04.005. PMid:17507188.

Silva JR, Figueiredo JR, van den Hurk R. Involvement of growth hormone $(\mathrm{GH})$ and insulin-like growth factor (IGF) system in ovarian folliculogenesis. Theriogenology. 2009;71(8):1193-208. http://dx.doi.org/10.1016/j. theriogenology.2008.12.015. PMid:19193432.

Silva PR, Soares HF, Braz WD, Bombardelli GD, Clapper JA, Keisler DH, Chebel RC. Effects of treatment of periparturient dairy cows with recombinant bovine somatotropin on health and productive and reproductive parameters. J Dairy Sci. 2017;100(4):3126-42. http://dx.doi.org/10.3168/jds.201611737. PMid:28215881.

Spicer LJ, Aad PY, Allen DT, Mazerbourg S, Payne AH, Hsueh AJ. Growth differentiation factor 9 (GDF9) stimulates proliferation and inhibits steroidogenesis by bovine theca cells: influence of follicle size on responses to GDF9. Biol 
Reprod. 2008;78(2):243-53. http://dx.doi.org/10.1095/ biolreprod.107.063446. PMid:17959852.

Sudo N, Shimizu T, Kawashima C, Kaneko E, Tetsuka M, Miyamoto A. Insulin-like growth factor-I (IGF-I) system during follicle development in the bovine ovary: relationship among IGF-I, type 1 IGF receptor (IGFR-1) and pregnancy-associated plasma protein-A (PAPP-A). Mol Cell Endocrinol. 2007;264(1-2):197-203. http://dx.doi. org/10.1016/j.mce.2006.10.011. PMid:17116363.

Tajima K, Yoshii K, Fukuda S, Orisaka M, Miyamoto K, Amsterdam A, Kotsuji F. Luteinizing hormone-induced extracellular-signal regulated kinase activation differently modulates progesterone and androstenedione production in bovine theca cells. Endocrinology. 2005;146(7):2903-10. http://dx.doi.org/10.1210/en.2005-0093. PMid:15817663.
Taylor VJ, Cheng Z, Pushpakumara PGA, Wathes DC, Beever DE. Relationships between the plasma concentrations of insulin-like growth factor-I in dairy cows and their fertility and milk yield. Vet Rec. 2004;155(19):583-8. http://dx.doi. org/10.1136/vr.155.19.583. PMid:15573950.

Thatcher WW, Moreira F, Pancarci SM, Bartolome JA, Santos JE. Strategies to optimize reproductive efficiency by regulation of ovarian function. Domest Anim Endocrinol. 2002;23(1-2):243-54. http://dx.doi.org/10.1016/S07397240(02)00160-1. PMid:12142241.

Yakar S, Adamo ML. Insulin-like growth factor 1 physiology: lessons from mouse models. Endocrinol Metab Clin North Am. 2012;41(2):231-47. http://dx.doi.org/10.1016/j. ecl.2012.04.008. PMid:22682628.

\section{Financial support: None.}

Author contributions: JAAR: Conceptualization, Data curation, Formal analysis, Writing - original draft, Project administration; BM: Data curation, Formal analysis, Writing - original draft; DAVA: Methodology, Project administration, Conceptualization; BGG: Funding acquisition, Resources, Writing - review \& editing; MTR: Methodology, Data curation, Writing - review \& editing; LMCP: Funding acquisition, Writing - review \& editing, Supervision; MNC: Funding acquisition, Resources, Supervision; AS: Methodology, Data curation, Supervision, Writing - review \& editing.

Conflict of interest: The authors have no conflict of interest to declare. 